Marquette University

e-Publications@Marquette

Economics Faculty Research and Publications

Business Administration, College of

9-1-2004

\title{
What Determines Public Education Expenditures in Russia?
}

Inna Verbina

Foundation for Enterprise Restructuring and Financial Institutions Development

Abdur Chowdhury

Marquette University, abdur.chowdhury@marquette.edu

Accepted version. This is the peer reviewed version of the following article: Verbina, I. and Chowdhury, A. "What determines public education expenditures in Russia?" The Economics of Tradition, Vol. 12, No. 3 (September 2004): 489-508, which has been published in final form at here: DOI. This article may be used for non-commercial purposes in accordance With Wiley Terms and Conditions for self-archiving.

Abdur Chowdhury was affiliated with the United Nations Economic Commission for Europe at the time of publication. 


\title{
What Determines Public Education Expenditures in Russia? ${ }^{1}$
}

Inna Verbina* and Abdur Chowdhury**

\begin{abstract}
Recent studies suggest that the allocation of expenditures in education is important for growth. The state of public education spending in many transition economies highlights the need for an assessment of the nature of education expenditures in these countries. This paper attempts to fill this gap in the literature by estimating the determinants of education expenditures in the Russian Federation. Results from panel data analysis show that revenue and the student-population ratio have a positive impact on education expenditures while the effect of population density is negative. Three regional variables also show significant impact. The income and price elasticity of public education expenditures are estimated to be 0.57 and -0.18 , respectively, a result comparable to studies from other countries. The results presented here provide insight into how fiscal institutions and the structure of the political process in Russia may affect the degree of resource allocation in the educational sector during the transition process.
\end{abstract}

\section{Introduction}

The thrust of systematic transformation in the post-Soviet Russian economic and social system has been to bring about the transition from an administrative government economic management system to a market-oriented economy with regulatory government functions. As expected, many features of the new economic system are not yet clarified and the forms of economic organization - both in private and, even more, in public goods production - are still being debated (Hare and Lugachyov, 1999). Consequently, various issues relating to the public and private financing of social sector activities, the public and private provision of social services, and the limits and effectiveness of privatization in the social sector have generated keen interest among both academicians and policy-makers.

In this context, a vigorous debate about the growth of public spending has been evident in public policy circles. In order to gain a better understanding of the factors that go into the decision-making process related to public spending in Russia, this paper focuses attention towards specific components of the government budget, in particular public education.

The Soviet educational system, with broad access and high levels of scholarly achievement, had long been a source of strength. However, it failed to adapt to the rapidly 
changing economic environment following the market-oriented transition beginning in the early 1990s. During this period, Russia has implemented changes in primary education, fiscal decentralization in the education sector, diversification at the secondary level and expansion of higher education. These rapid attempts at decentralization have not been well designed, since there has been no corresponding transfer of resources and the levels of budget responsibility have remained unclear (Canning et al., 1999).

There is a general consensus in the literature that expansion in the skills, knowledge, and capacities of individuals - increasing human capital - is critical for economic growth (see, among others, Dabla-Norris and Matovu, 2002; Greenaway and Haynes, 2003; and Krueger and Lindahl, 2001). ${ }^{2}$ Education plays a key role in creating human capital. Thus the high estimated rates of return to schooling is often cited as justification for increased public investment in more and better quality schools. ${ }^{3}$ At the same time, given budgetary constraints, many countries face important trade-offs between education and other types of expenditures, such as domestic infrastructure. For example, fiscal austerity programmes often make it necessary for countries to make difficult choices about which components of public expenditures should be reduced or reallocated within the overall budget. This is especially true for a transition economy like Russia where acute financial constraints force the government to make critical, and sometimes unpopular, choices.

Baqir (2002) has shown that countries at similar levels of economic development vary considerably according to how much their governments spend on the education sector. The size of education spending also changes within countries over time. Given this significant variation in education expenditures across and within countries, a natural question arises as to what factors help to explain this difference. This issue is interesting from a public policy perspective since spending on education has a significant positive redistributive effect and because it increases the human capital of the economy and can lead to direct growth effects (Barro, 1991) and indirect spillover benefits for the rest of the economy (Baqir, 2002). Despite the importance of this issue for the transition economies, there is surprisingly little formal theoretical or empirical work.

As far as we know this is one of the first studies which tackles this issue of public policy economics with the realistic expectation of obtaining results comparable in quality and reliability to those available in developed countries. The paper fills a gap in the literature by conducting an empirical analysis of the determinants of public expenditures on the general education system in Russia. General education is selected since the demand function (or household preferences) for this type of education is more complicated and diverse but at the same time less well-known than those for the other types of education, such as graduate and post-graduate. Moreover, greater 
opportunities for labour market success and earning potential in Russia have increased the returns to acquiring education. This has reinforced the importance of general education, which is mostly financed with public funds, leading many students to prolong their schooling period (Laporte and Ringold, 1997).

A number of studies have emphasized income and price effects as determinants of public sector growth, identified as Wagner's law and Baumol's disease, respectively (Falch and Rattso, 1997). The preferences of economic agents over economic spending, or, alternatively, the 'demand' for public education spending, can be predicted using the income and price elasticity of demand for education expenditures. In their evaluation of California's education finance reform, Fernandez and Rogerson (1995) show that predictions for the change in total spending can vary by as much as 40 percent depending upon income and price elasticity. We estimate these two types of elasticity, using the regional variations among different jurisdictions of the Russian Federation. In the inter-budget context, major changes in public education spending could be achieved by altering regional budget behaviour which, in turn, may be influenced by the federal government.

The analysis in the paper, based on these fiscal and regional characteristics, is similar in spirit to that reported in Fernandez and Rogerson (1997) and Poterba (1996). They use a panel dataset for the fifty states in the US to examine the effects of demographics (Poterba, 1996) and growth in income and students (Fernandez and Rogerson, 1997) on public education spending.

Two separate frameworks are developed in the paper. In the baseline framework, we estimate income elasticity, holding prices for public goods constant in real terms across regions. In the second framework, we allow relative price changes in public goods among regions within the inter-budget fiscal framework.

The paper is organized as follows. In the next section we provide a brief background on the Russian educational system, highlighting the characteristics most important for our estimation strategy. Some of the factors involved in the decision-making process are discussed in Section 3 along with the model. The baseline framework is described in Section 4 and the estimation results are presented in Section 5. Section 6 reports the framework with relative prices and the calculation of price elasticity. The paper ends with concluding remarks in Section 7.

\section{The state of general education ${ }^{4}$}

The Russian Federation inherited a fairly well-developed and mature educational system from the former Soviet Union. During the Soviet era, most school age children had access to 
general education and literacy was almost universal. Enrolment rates, especially those for pre-school and basic education, equalled or exceeded those in Western developed countries (Laporte and Ringold, 1997). However, the transition to a market economy exposed certain weaknesses in the education system, which was tailored to the needs of a centrally-planned economy. Since education was directed toward the productive and ideological goals of the socialist regime, its ability to respond to changing economic structures and employment patterns essential for the success of a market economy was limited.

With a view to bringing greater accountability to the education system, a large part of the education sector was decentralized under the 1992 Law on Education (Russian Federation, 1995). Under this law, the responsibility for general education and school finance was entrusted to the regional (oblast) and local (rayon) level authorities while professional and university education was mostly to be financed by the federal government. The local governments usually do not possess the necessary tax resources to meet their expenditure obligations. The regional government allocates resources in the consolidated regional budget and decides on the share of each local municipality.

To reduce fiscal disparities among territories, the federal government subsidizes regional budgets through various instruments, the most significant of which is the Fund for the Financial Support of Subjects of the Federation (FFSSF). Under a three year government programme for the reform of inter-budgetary relations for 1999-2001 (corresponding to our sample period) the size and allocation of the regional transfers from the fund depend on the tax capacity of the territory and the cost of public goods provided, which, in turn, is determined by geographic and demographic factors within the region. Several types of federal transfers also exist outside the FFSSF programme including loans, debt restructuring and mutual settlements (Lavrov et al., 2001).

The regions share a certain ambiguous joint responsibility with the federal government for education spending along with health, social policy, and economic subsidy. The federal government participates in the financing of the education sector through unconditional federal transfers. ${ }^{5}$ Although most regions have benefited from such transfers, fiscal relations between the federation and the regions is in many cases unclear since responsibilities overlap (see Lavrov et al., 2001). ${ }^{6}$

The financial transfers from the federal government to the regional governments have recently decreased both in absolute terms and relative to the amounts the regions themselves spent. Fluctuating between 3.4 and 4.5 percent of GDP, public expenditure on education has also fallen during the 1990s (Fretwell and Wheeler, 2001). This declining trend has been one of 
the major problems facing the education sector in Russia. While the gradual decrease in funding has continued for the last two decades, the transition-related reductions in real expenditures have greatly aggravated the situation. ${ }^{7}$

In real terms, public spending on education fell at a rate of about 6 percent per year. For instance, in 1998 consolidated public education expenditures accounted for 3.8 percent of GDP, compared to about 5.5 percent in OECD countries (World Bank, 2001). The consolidated budget for education amounted to 189 billion Rubles (3.3 percent of GDP) in $2000 .^{8}$

Educational expenditure assignments in the Russian Federation are divided across the federal, regional and local budget lines. The federal government is responsible for all university, research institute, technical and vocational school expenditures; ${ }^{9}$ the regional and local budgets include some high schools, boarding schools, comprehensive primary and secondary schools, nurseries and kindergartens (Craig et al., 1997; OECD, 2000). The federal government's share of total public education expenditures was only 19 percent in 2000, while the regional and local governments accounted for the remaining 81 percent. For the purpose of this study, general education expenditures are defined as all expenditures undertaken by the regional and local governments.

In the course of the transition process, the size and diversity of Russia, reinforced by increasing decentralization of government, led to growing regional inequality as well as inequality in access to education. A number of regions have been able to capitalize on their resource endowments, location and other factors to increase per capita income relative to the rest. These regions with high per capita incomes have been able to spend more on education and other social areas. This variation in endowments and expenditure composition will enable us to estimate the differential impact of the demand function for education and the related income and price elasticity.

Given the extent of its territory, the extreme climate and dispersed population, the federal structure of government and the on-going transition from a planned to a market economy with resulting acute financial constraint, Russia faces a particularly difficult task in adapting and updating its general education system to meet emerging needs. In this context, it is important to discover what factors influence the expenditures on education. This provides a rationale for the model that will be presented in the next section.

\section{Model}

A number of models, such as the median voter model or the agenda setting model (see Romer et al., 1992) are available as the foundation for federal and regional government

5 Verbina \& Chowdhury 
preferences. Since the agenda setting model assumes well-developed party systems and multi-dimensional decision-making processes, it may not reflect the current decision-making process in Russia.

One can argue that optimum decisions are not attainable at the multi-level government structure, since regional governments cannot internalize the full set of externalities which a particular decision brings about. The regional government has its own preference structure which, in general, does not coincide with the federal government's pursuit of 'national interest', which may include income distribution considerations, macro policy targets, and so on.

Given a set of instruments to affect regional government spending patterns, the federal government can attain the second best solution in the national context if it possesses accurate knowledge about the expenditure behaviour of the subjects of the federation. ${ }^{10}$ As discussed in the literature, economic models of public sector growth are based on income and price elasticity as driving forces of expenditure patterns - since they show how income affects different components of spending and how the price effect reflects various cost elements (Falch and Rattso, 1997). Price and income elasticity are parameters, which determine the expected reaction of the regional authority to federal fiscal and economic policies, thereby allowing the federal authorities to effectively employ the instruments available, for example, tax policy, earmarked and matching grants, voucher schemes. In the paper, we analyze the demand function for public goods within a median voter framework as developed in Meltzer and Richard (1981) and only offer empirical regularities regarding the effects of political considerations on education expenditures.

The broad literature on the determinants of educational spending is based on cross-sectional evidence and aggregate measures of spending. ${ }^{11}$ Given the variation of regional data across the Russian Federation, we can estimate the parameters of the demand function based on the observations. In the model, the median voter decides on budget shares for particular types of public good. Although the distribution of income across the regions is different, we assume that there is no correlation between the median voter's income and his preferences for particular types of public goods. He has the same demand function irrespective of his position in the income scale and his decision on the composition of public service is based on the size of the public budget.

\section{Baseline framework}

Earlier studies on educational expenditures have used cross section analysis, using either individual survey data or data for a sample of school districts. ${ }^{12}$ However, Fernandez and 
Rogerson (1997) have argued that time series relationships in the data can provide useful complementary information. Following their suggestion, we perform a panel analysis with the cross section and time series, pooling data from 88 regions in the Russian Federation over the calendar year 1999-2000. The sample period is constrained by the availability of consistent data series for all the variables considered in this model. The basic specification of the model that will be used in the paper is given by:

$$
\begin{gathered}
\log \left(y_{i t}\right)=\alpha+e \log \left(x_{i t}\right)+\sum_{k} \beta_{k} z_{k i t}+u_{i}+\varepsilon_{i t} \\
i=1,2, \ldots N, t=1,2
\end{gathered}
$$

where $y_{i t}$ represents general education expenditures ${ }^{13}$ in region $i$ in period $t, x_{i t}$ represents budget revenues in region $i$ in period $t$, and $z_{k i t}$ are the remaining $k$ independent variables. The constant term is $\alpha, u_{i}$ represents the region specific variable and $\varepsilon_{i t}$ is assumed to be a random error with zero mean.

The dependent variable is measured as the spatial and inflation-adjusted per capita expenditures on general education (CPEDEXP). ${ }^{14}$ Total budget revenue is also measured in spatial and inflation-adjusted per capita form (CPREV). Among the other variables, the student-population ratio (STUDPPOP) represents the number of pupils per thousand inhabitants enrolled in schools in the 1999-2000 school year. This variable is a reasonable proxy for the education benefit incidence for region $i .{ }^{15}$ Population density per square kilometre is represented by the variable (PDENC). Following Goskomstat, geographical differences across regions are captured in the model by sub-dividing the regions into eleven groups, R1 . R R $11 .{ }^{16}$ Since the logarithms of CPEDEXP, CPREV and PDENC are used in the model, the estimated parameters corresponding to these variables give the elasticity properties of education demand. ${ }^{17} \mathrm{~A}$ time variable is also included in the equation.

Our empirical analysis combines differences among the regions and changes over time in one model. Such a procedure increases the variation of the data and improves available degrees of freedom to achieve efficient parameter estimates. It also helps to take regional effects into consideration.

Data for the 88 regions have been collected for the calendar years 1999 and 2000 giving a total of 176 observations for each variable. The short period of time is unfortunate but cannot be avoided when researching economies in transition. Moreover, in the case of Russia, the currency crisis of 1998 significantly affected the data for that year. Therefore care was taken to avoid figures for 1998. Data on total revenue, expenditures on education and federal fiscal 
grants ${ }^{18}$ are taken from the Ministry of Finance of the Russian Federation. ${ }^{19}$ The regional price index is constructed by the Russian State Statistical Agency (Goskomstat) and is calculated on the basis of a basket of 25 items. The 2000 GDP Inflation index for the Russian Federation is used to adjust the 1999 data to 2000. The figure is taken from the Bureau of Economic Analysis, Moscow. The data on population, demographic structure and regional subdivision into 'geographical rayons' are also taken from Goskomstat. Summary statistics for the variables are given in Appendix Table A1.

Given the nature of the data, we expect individual region-specific heterogeneity to exist within the model. Regions are likely to vary systematically in terms of weather conditions, infrastructure, productive efficiencies, historical and institutional factors and so on. Consequently, the use of standard least square methods - which ignore such differences - would lead to biased estimates. Moreover, the direction of the bias cannot be identified a priori. An alternative choice would be the use of a panel data analysis.

In order to capture the cross-sectional parameter heterogeneity, two types of models are generally proposed in the literature. The random effect model treats the region-specific variables as time-invariant random variables, which are independent of the explanatory variables of the model. The fixed effects model (the within, or least squares dummy variable estimator), on the other hand, allows individual effects to be correlated with the regressors. The results of different estimates can vary substantially if the time period $(T)$ analyzed is small and the cross-sectional units $(N)$ are large.

The choice of the model can be based solely upon a priori assumptions. The test of our panel dataset for unobserved effect (Breusch-Pagan Lagrangian multiplier effect) show that the individual effect exists and this supports the use of panel estimation, rather than the pooled GLS method. ${ }^{20}$ Next, the possibility of applying the more efficient random effects model against the fixed effects model is checked using the Hausman chi-squared statistic. The test examines the correlation between the region-specific effects and the explanatory variables. In the presence of the correlation, the fixed effects estimator is consistent while the random effects estimator is biased. ${ }^{21}$ Failure to reject the null hypothesis of no correlation would, however, lead us to the adoption of the random effects model.

The panel regression results are shown in Table 1. Estimations have been carried out using the GLS random effect procedure as given in the STATA statistical package. The model indicates a good fit with the data, explaining about 90 percent of the variation in educational expenditures across regions. Three specification tests are reported in the table. First, the Breusch-Pagan Langrange Multiplier test is used to test the statistical significance of the 
regional random effects. The null hypothesis is that the variance of the region-specific error component is equal to zero, that is, $\operatorname{Var}(u)=0$. The test statistic, calculated from the OLS residual of the panel regression has a chi-square distribution with one degree of freedom. The calculated test statistic of 33.85 comfortably rejects the null hypothesis of zero variance at the 1 percent significance level. This indicates that the region-specific effects are statistically significant.

Second, we test the orthogonality of the region-specific error component $u$ with the explanatory variables, a condition that is necessary for avoiding inconsistency that can result from omitted variables in the random effects specification. As discussed earlier, the Hausman correlation test is used for this purpose. Under the null hypothesis of zero correlation between the error term and the regressors, the test statistic is asymptotically distributed as chi-squared with the degrees of freedom equal to the number of regressors. The calculated test statistic does not reject the null hypothesis of orthogonality at the one percent significance level. This justifies the use of the random rather than the fixed effects model. ${ }^{22}$ Finally, given that only the asymptotic properties of the random effect estimators are known, a chi-square statistic, instead of an F-statistic, is reported for the overall significance of the coefficient. Considered jointly, the calculated chi-square value shows that the coefficients are significant. ${ }^{23}$ The time dummy variable included in the model turns out to be significant.

\section{Estimation results}

Now let us turn our attention to the coefficient estimates. The coefficient of per capita revenue, which is used as a proxy for income, is positive and highly significant. As the decision of the median voter in our model is constrained by the budget, the coefficient estimate indicates that regions with higher income tend to attract higher education expenditures. The numerical value of 0.57 shows that a one percent change in per capita budget revenue (CPREV) changes per capita general education expenditures (CPEDEXP) by 0.57 percent. ${ }^{24}$ Given the logarithmic form of the function, this measures the income elasticity of demand for education and confirms that education is a normal good in Russia. We can consider the elasticity value as a mixed blessing. On the one hand, it is quite low suggesting that Russian households consider education expenditures to be a necessity. A high income elasticity, on the other hand, would have indicated that education expenditure is a luxury. The elasticity figure confirms overwhelming evidence of income-inelastic educational services (see Craig and Inman, 1986;

Romer et al., 1992) and lies within the range of income elasticity reported for other countries. ${ }^{25}$

However, from a policy perspective, the elasticity figure may be a source of concern. 
Policy-makers cannot depend on general increases in budget revenue to lead to proportionally higher expenditures on education. For every doubling of regional income, the budget share spent on education increased by about a half. Combined with the finding, discussed later in this section, that the level of expenditures vary significantly by income level in different regions, the results show that the federal government needs to address the inability of poorer regions to incur additional expenditures. This is similar to the findings for Peru as reported in World Bank (2001).

The ratio of students to the population also has a significant positive impact on educational expenditures. Evaluated at the mean value, the coefficient estimate indicates that an increase in the average ratio of students to population by one percentage point leads to only one-half of one percentage point increase in educational spending. Interestingly, this result for the Russian regions is in contrast to those reported for the US states in Poterba (1996) and Fernandez and Rogerson (1997). Both these studies found that increasing the fraction of the population of school age has little effect on education spending per student. Our findings, if in fact they reflect tensions between generations in the allocation of funds, suggest that the current downward demographic trend in the Russian Federation may lead to a long-term increase in the level of per student government financing of general education indicating the presence of economies of scale.

Population density has a negative impact on total educational expenditures. High population density enables regional governments to reduce the cost of educational service provided because of the developed infrastructure and/or economies of scale. The results show that regional location is another important factor in explaining the behavior of educational expenditures. Models are initially estimated using eleven regional variables. However, only three turn out to be statistically significant. The remaining eight insignificant regional variables are, therefore, dropped and the model re-estimated. The three regions that significantly affected the dependent variable are located in geographical areas that possess particular properties which influence expenditures on education.

The regions of European North (R1) probably have, on average, a more severe climate than other regions. The costs of providing comparable educational services in this region are higher than those in other regions and so it should receive more government money. The positive sign associated with this variable provides support that this occurs. The positive sign for the Ural region (R8) can be explained by the high industrial development that has taken place in this region and the resulting high demand function for education. The variable R7 represents the North Caucasus region and the negative sign for this variable reinforces the proposition that in highly populated regions, local educational expenditures can lead to future migration of students. 
The results indicate that the regional government, anticipating such a process, is less interested in spending on education. The findings can also be attributed to the dominance of agriculture in the local economy and the favourable climate which help the regional authorities to save money by reducing utility expenses on buildings.

\section{Framework with relative prices}

In the previous section, we considered that the federal financial aid included in the total regional budget revenue had only an income effect on consumption, by assuming that prices for public goods in real terms ${ }^{26}$ are the same across regions. In this section, we estimate the price elasticity of demand for public education expenditures, capturing the differences in the prices of public goods among regions within the inter-budget fiscal framework. The idea is that the federal government transfer, rather than directly changing the size of the regional fund, decreases the price for public service to the local taxpayers. The regional government adjusts its behaviour according to the share of public expenditures to be paid by the federal government. Given the exogenous prices for public and private goods, the region decides on the scope and size of public and private expenditures.

Within this framework, the pivotal voter disposes of his own income, $C_{i}$, and the regional per capita government revenue, $R_{i}$, so he can consume the value $W_{i}$.

$$
W_{i}=C_{i}+R_{i}
$$

When the region $i$ obtains the transfer, the total budget constraint for the voter within the jurisdiction is given by:

$$
W_{i}=C_{i}+R_{i}+G_{i}
$$

where $G_{i}$ is the amount of per capita federal transfer for the region. ${ }^{27}$ In general, each ruble spent on public goods is partially paid by the federal government through the grants from national resources to regional budgets.

The expenditure effect of federal grants could be measured only by the income effect, if the decisive voter could convert federal lump-sum grants into either private income through tax reduction or into an increase in both private and public consumption due to a relaxation of budget constraint. But, due either to fiscal illusions or political considerations, the taxpayer cannot successfully transform the public money into private consumption. Moreover, the federal government, though formally limited to a lump sum grant system, is seemingly trying to 
encourage regional public expenditures. This leads to stimulating effect of inter-budget federal policy. Under these scenarios, a flypaper effect can be observed. ${ }^{28}$ Therefore, the partial financing through federal transfers ensures an income as well as price substitution effect, which is usually associated with matching grants. The resulting relative price variation across regions can be used for estimating price elasticity.

The net price of public goods for the average taxpayer of the jurisdiction $i$, is given by

$$
p=R_{i} /\left(R_{i}+G_{i}\right)
$$

where $p$ is the net price.

Under this framework, federal transfers influence the expenditure behaviour through the price-substitution effect. The regional government could decide on the size and composition of the public spending at the expense of the regional tax payer, but it is the federal government which through federal grant policy determined the price of the public goods provided. The federal transfers to regional budgets alter the price of public goods including public education relative to that of private goods. Given the set of exogenous prices for both public and private goods, the median voter decides on the quantity consumed based on his preference map. Therefore, given the difference in the size of federal transfers, the price variation can be exploited to estimate price elasticity within the complete demand function (covering both public and private consumption).

The plausible logarithmic demand function allows us to estimate price elasticity for every good in the consumption basket, including individual public items: ${ }^{29}$

$$
\log \left(y_{i t}\right)=\alpha+e \log \left(x_{i t}\right)+e_{p} \log \left(p_{i t}\right)+\sum_{k} \beta_{k} z_{i t}+u_{i}+\varepsilon_{i t}
$$

where $x_{i t}=$ own regional per capita value added, $p_{i t}=$ price for public education, $y_{i t}=$ per capita public education expenditures, $e=$ income elasticity, $e_{p}=$ price elasticity, and $u_{i}=$ region specific effect. Regional value added (an analogy to national GDP) of the jurisdiction $i$ is used as a income capacity proxy, which is a reliable measure of the potential ability of the region to generate public as well as private income. Data on value added are taken from the Ministry of Finance.

The equation is estimated by a panel data random effects model. The results are given in Table $2 .{ }^{30}$ The robustness of this particular panel estimation is examined using a battery of tests 
including the Hausman specification test, Breusch-Pagan Lagrangian Multiplier test and the Wald chi-square test. Results from all these tests, reported in Table 2, show that the random-effects model estimated in this table is appropriate and efficient. The R-square of about 0.81 is quite high for panel data. The coefficient of the RREV variable measures the price elasticity as the demand for education. The coefficient is statistically significant and has the anticipated negative sign, suggesting a substitution effect. The numerical value shows a price elasticity of -0.18 . Thus an inelastic demand for public education is evident in Russia. Chandler (2001) also reported inelastic price elasticity for the Connecticut school system in the United States. However, the magnitude of the price elasticity was much higher $(-0.39) .{ }^{31}$

\section{Conclusion}

Economic growth and the development of a civil society during transition depend upon the capacity of well-educated workers and citizens to respond to changing economic conditions. Everywhere education has emerged as an essential component of the transition to a market economy. The Russian Federation is no exception. Education financing in Russia is undergoing changes on a number of fronts. On the one hand, the finance of education is becoming multi-level and multi-channel while, on the other hand, normative specifications and personal financing decisions are dominating discussion in the public policy arena. In this context, an exercise in determining the factors that influence public education expenditures is not only informative but also essential to understand the process that underlies a successful transition in the education sector.

The paper uses panel data to estimate the parameters of demand for public education expenditures. Results show that revenue and the student-population ratio have a positive impact on education expenditures while the effect of population density is negative. Three regional variables also show significant impact. The income elasticity of public education expenditures is estimated to be 0.57 which is comparable to studies from other countries. Combined with the finding that the level of expenditures vary significantly by income level in different regions, the results show that federal government needs to address the inability of poorer regions to incur additional expenditures. The paper also estimates the price elasticity that turns out to be -0.18 , indicating inelastic demand.

The results presented here raise, but do not resolve, questions about how fiscal institutions and the structure of the political process in Russia may affect the degree of resource allocation in the educational sector during the transition process. It will be interesting to see how both the people and the policy-makers in the Russian Federation respond to this daunting task in 
the near future.

\section{Notes}

*Foundation for Enterprise Restructuring and Financial Institutions Development, 3/5 Smolensky Blvd., Moscow, Russia. E-mail: iverbina@fer.ru

**Economic Analysis Division, United Nations Economic Commission for Europe, Palais des Nations, 1211 Geneva 10, Switzerland. E-mail: abdur.chowdhury@unece.org

${ }^{1}$ We would like to thank the editor and two anonymous referees for extremely helpful comments on earlier drafts. John Micksell also provided excellent suggestions regarding the initial draft. The usual disclaimer applies. This paper does not necessarily represent the views and opinions of the UNECE.

${ }^{2}$ See Barro and Lee (2000) for a cross-country study emphasizing the importance of education for economic growth.

${ }^{3}$ Judson (1998) reports that countries whose allocation is inefficient gain little in output and growth from their investments in education.

${ }^{4}$ For a more detailed discussion on the education system in Russia and other related issues, see, among others, Russian Federation (1995) and OECD (1997). Fisher (1995) includes a theoretical discussion of the relationship between state and local governments. Lavrov et al. (2001) describe the current state of the federal grant system in Russia.

${ }^{5}$ The Federal financial aid is not earmarked and is used for general expenditure obligations of regional governments. The long-term strategic plan of the government reveals an intention to move towards a type of matching educational grant, where the regions that have spent more of their own resources on education in previous years could expect a rise in general federal transfers. The government also intends to attract more private money into the formal education system thus providing parents with an opportunity to co-finance education.

${ }^{6}$ The decentralization of school finance and school administration under the new legislation led to further differentiation of available resources across and within regions. Sixteen of the country's 88 regions now spend more than one-third more per student in compulsory education than do the eighteen regions with the lowest schools spending (authors' calculation).

${ }^{7}$ The proportion of GDP which Russia allocates to education has declined from 7 percent in 1970 to around 3.4 percent in 1992. The figure has fluctuated in the 3-4 percent range during the last decade. Among the developed countries the United States allocates 5.5 percent, France, 5.4 percent, and the United Kingdom, 5.3 percent (OECD, 2000). Figures for 1998/99 for other regions range from a low of 2.5 percent in South Asia to a high of 5.8 percent in the Middle 
East and North Africa (Dabla-Norris and Matovu, 2002, Table 6).

${ }^{8}$ The following table shows the general expenditures on education (as a percentage of GDP) at different levels of government (Source: TACIS, 2001):

\begin{tabular}{lllll}
\hline & 1998 & 1999 & 2000 & 2001 (est.) \\
\hline Federal and regional-consolidated budget & 3.83 & 3.60 & 3.32 & 3.0 \\
Federal budget & 0.61 & 0.52 & 0.63 & N/A \\
Regional budget & 3.22 & 3.08 & 2.69 & N/A \\
\hline
\end{tabular}

${ }^{9}$ In 2000, about 60 percent of the federal budget share of educational expenditures went to higher education. On the other hand, the major share of the regional budget went into general education (61 percent), followed by primary education (18 percent) and vocational training (6 percent).

${ }^{10}$ There may be other reasons why a Pareto optimum may not be reached. Interest groups may block a Pareto improving political trade out of fear that it will favour a particular group. In fact, this can be thought of as a 'third best' world where constitutional constraints on political decision-making are taken into account.

${ }^{11}$ See Falch and Rattso (1997) and Romer et al. (1992).

${ }^{12}$ Bergstrom et al. (1982) present a detailed literature survey on this issue.

${ }^{13}$ Estimation of the demand function requires the quantity of goods consumed. Since reliable data on quantity of educational output are not available, education expenditures are used as a proxy. Here, education expenditures $\left(y_{i}\right)$ can be expressed as the product of units of education consumed $\left(q_{i}\right)$ and price of the unit $\left(p_{i}\right)$, i.e., $y_{i}=q_{i} \times p_{i}$. Assuming that the price of one unit of education is unity, education expenditures is a proxy for quantity, $y_{i}=q_{i}$.

${ }^{14}$ Falch and Rattso (1997) also use a similar variable.

${ }^{15}$ Falch and Rattso (1997) and Schultz (1996) have used a similar variable. Schultz (1996) has shown that the number of school-age children as a share of total population has varied widely over time due to the demographic transition in low-income countries and the baby-boom in high-income countries.

${ }^{16}$ The regional groupings are as follows: $\mathrm{R} 1=$ North, $\mathrm{R} 2=$ Northwest, $\mathrm{R} 3=$ Central, $\mathrm{R} 4=$ Volga-Vyatka, R5 = Central Chernozem, R6 = Volga, R7 = North Caucasus, R8 = Urals, R9 = Western Siberia, R10 = Eastern Siberia and R11 = Far East.

${ }^{17}$ Other functional forms, such as simple linear specification were also examined. The best results were obtained with log specification.

${ }^{18}$ The grant consists of two budgetary items - direct transfers and mutual settlements.

${ }^{19}$ Since the general education is mostly financed through the regional budgets, we used the 
regional fiscal data which includes both the regional and local components, without considering federal budget expenditures on education. At the regional level, general school education accounts for the dominant share of education expenditures.

${ }^{20}$ The specific results are discussed later.

${ }^{21}$ See Wooldridge (2002) for a more detailed discussion.

${ }^{22}$ This also addresses the issue of slope heterogeneity. As shown in Rebucci (2003), relatively high slope heterogeneity is a source of concern for pooled estimators in the fixed effect models. Test results rejecting the use of a fixed effect model indicate that slope heterogeneity is no longer a problem.

${ }^{23}$ Fernandez and Rogerson (1997) have shown that the closeness of the observations over time can lead to serial correlation in the error terms. As pointed out by a referee, government spending can exhibit some inertia even after controlling for income and a time-invariant component. Tests for serial correlations have been performed using the command gtlee in STATA in order to specify the particular structure of the idiosyncratic errors with an autocorrelation coefficient. But no evidence of serial correlation is detected. This may be due to the short length of the sample where the inertia does not have enough time to play out.

${ }^{24}$ Although regional revenue may not be a perfect proxy for income, for a number of reasons we feel that it is a suitable proxy in this particular case. First, the data on alternatives, such as cash income and wages at the household level (published by Goskomstat), suffer from a number of methodological shortcomings and are difficult to estimate due both to significant home production activity and to a significant shadow economy. The presence of a large non-cash component, especially in the agricultural regions, makes any data on cash income less representative while home production accounts for a significant share of household income, ranging up to 40 percent in certain regions. Second, under the current system in Russia, the major part of budget revenue comes not from individual income tax, but from direct and indirect duties on business. Within the framework of similar taxation legislation set by the federal government, the level of budget revenue can be considered a reasonable proxy for the welfare level of the region. Moreover, budget revenue is better at measuring the ability of regions to finance public expenditures because the allocation decision of the regional government is based on the budget at their disposal. However, in order to see if the results are sensitive to the variable employed, the equation has been re-estimated using a different proxy for income - per capita value added within the region. This is analogous to a country's GDP which is routinely used in inter-country analysis. The results (not reported here) are similar to those given in

Table 1 . The income elasticity with the use of value added as a proxy of income is 0.55 
compared to 0.57 in Table 1. But value added also has its own problem since value added within a territory does not mean that the proportional amount of income is generated by the value (the difference is explained by large variation in industry structure across regions, problems with accurate estimation of value added between the territories, etc.). Public revenue reflects the adequate status of the region.

${ }^{25}$ Recent estimates for income elasticity range from a low of 0.27 in Peru (World Bank, 2001) to a high of 0.73 in Kenya (Mwabu, 1994). However, Schultz (1996) reports an income elasticity of greater than one in a panel estimate from sixty countries.

${ }^{26}$ Spatial price adjustment was made all fiscal figures.

${ }^{27}$ For the purpose of this study, all kinds of transfers are combined into one variable, $G$.

${ }^{28}$ The flypaper effect shows that public income is disproportionately spent on private consumption while a federal grant is primarily spent on public services. Knight (2000) reports that empirical research in the United States has found that state government public spending is increased far more by federal grant receipts than by equivalent increases in the level of private income of the constituents.

${ }^{29}$ In spite of public transfer changing the prices for all public goods, we can still use a standard demand function for estimating the price elasticity of public education. In the standard setting of a logarithmic demand function for a good (in our case, public education consumption) the equation should include the explanatory variables that are multipliers for compensated cross-price elasticity of the good in question along with all other goods and their prices. But according to the Stone decomposition method, these values are significantly different from zero only for the 'close' substitutes and complements of public education. For public goods other than education, the price indeed changes due to federal transfers, but the compensated cross-price elasticity of public education spending with other public goods is not significant; (e.g., health or public transport service consumption could not be considered a close substitute to education consumption, so compensated cross-price elasticity is zero, while the cross-price elasticity is significant since it includes the income elasticity component). In contrast, a close substitute for public education is private education consumption, the price of which is not subject to change due to federal transfers and is, therefore, captured by the constant term in the equation (see Deaton and Muellbauer, 1980 on this issue).

${ }^{30}$ Dahlberg and Jacob (2000) have shown that, for a median-voter model, fixed-effect models suffer from an endogeneity problem leading to a potentially sluggish adjustment process. The use of a dynamic model, such as a random-effects model controls for the endogeneity and provides validity to a log-linear model as used in this paper. 
${ }^{31}$ Previous estimates of tax-price elasticity for median-voter models of the effects of grants-in-aid to school districts in the United States ranged between -0.09 and -0.34 (Chandler, 2001).

\section{References}

Baqir, R. (2002). 'Social sector spending in a panel of countries', International Monetary Fund Working Paper WP/02/35, Washington, DC: IMF.

Barro, R. J. (1991). 'Economic growth in a cross section of countries', Quarterly Journal of Economics, 106(2), pp. 407-43.

Barro, R. J. and Lee, J. (2000). 'International data on educational attainment: Updates and implications', National Bureau of Economic Research Working Paper, No.7911, Cambridge, MA: MIT Press.

Bergstrom, T., Rubinfield, D. and Shapiro, P. (1982). 'Micro-based estimates of demand functions for local school expenditures', Econometrica, 50, pp. 1183-1205.

Canning, M., Moock, P. and Heleniak, T. (1999). 'Reforming education in the regions of Russia', World Bank Technical Paper No.457, Washington, DC: World Bank.

Chandler, M. W. S. (2001). 'The median-voter model versus the bureaucracy model of school finance equalization aid', mimeo, EuroFaculty Vilnius Centre, Vilniaus Universitetas, Lithuania.

Craig, J., Norregaard, J. and Tsibouris, G. (1997). 'Russian Federation', in Ter-Misassian, T. (ed.) Fiscal Federalism in Theory and Practice, Washington, DC: IMF.

Craig, S. and Inman, R. (1986). 'Education, welfare and the new Federalism: State budgeting in a Federalist public economy', in Rosen, H. (ed.) Studies in State and Local Public Finance, Chicago: University of Chicago Press.

Dabla-Norris, E. and Matovu, J. (2002). 'Composition of government expenditures and demand for education in developing countries', International Monetary Fund Working Paper WP/02/78, Washington, DC: IMF.

Dahlberg, M. and Jacob, J. (2000). 'Sluggishness, endogeneity and the demand for local public services', mimeo, Department of Economics, University of Uppsala, Sweden.

Deaton, A. and Muellbauer, J. (1980). Economics and Consumer Behavior, Cambridge: Cambridge University Press.

Falch, T. and Rattso, J. (1997). 'Political economic determinants of school spending in Federal states: Theory and time-series evidence', European Journal of Political Economy, 13, pp. 299-314.

Fernandez, R. and Rogerson, R. (1997). 'The determinants of public education expenditures:

18 Verbina \& Chowdhury 
Evidence from the States, 1950-1990', National Bureau of Economic Research Working Paper, No.5995, Cambridge, MA: NBER.

Fernandez, R. and Rogerson, R. (1995). 'Education finance reform and investment in human capital: Lessons from California', mimeo.

Figlio, D. (1997). 'Did the tax revolt reduce school performance?' Journal of Public Economics, 65(3), September, pp. 245-69.

Fisher, R. (1995). State and Local Public Finance, New York: McGraw Hill Company.

Fretwell, D. and Wheeler, A. (2001). 'Russia: Secondary education and training', Human Development Network, Secondary Education Series, Washington, DC: World Bank.

Greenaway, D. and Haynes, M. (2003). 'Funding higher education in the UK: The role of fees and loans', Economic Journal, 113, F150-F166.

Hare, P. and Lugachyov, M. (1999). 'Higher education in transition to a market economy: A case study', Centre for Economic Reform and Transformation working paper no. 17, Edinburgh: CERT.

Judson, R. (1998). 'Economic growth and investment in education: How allocation matters', Journal of Economic Growth, 3, December, pp. 337-59.

Knight, B. (2000). 'The flypaper effect unstuck: Evidence on endogenous grants from the Federal Highway Aid Program', mimeo, Board of Governors of the Federal Reserve System, Washington, DC, September.

Krueger, A. and Lindahl, M. (2001). 'Education for growth: Why and for whom', Journal of Economic Literature, 39, pp. 1101-36.

Laporte, B. and Ringold, D. (1997). 'Trends in education access and financing during the transition in Central and Eastern Europe', World Bank. Technical Report No.361, Washington, DC: The World Bank.

Lavrov, A., Litwack, J. and Sutherland, D. (2001). Fiscal Federalist Relations in Russia: A Case for Subnational Autonomy, OECD Centre for Cooperation with Non-Members, Paris: OECD.

Meltzer, A. and Richard, S. (1981). 'A rational theory of the size of Government', Journal of Political Economy, 89(5), pp. 167-84.

Mwabu, G. (1994). 'Household composition and expenditures on human capital inputs in Kenya', working paper no. 731, Yale University, New Haven, CT.

OECD (1997). 'The reform of education in new Russia: A background report for the OECD review of Russian education', Paris: OECD.

OECD (2000). OECD Economic Surveys 1999-2000: Russian Federation, Paris: OECD. 
Poterba, J. (1996). 'Demographic structure and the political economy of public education', National Bureau of Economic Research Working Paper No.5677, Cambridge, MA: NBER.

Rebucci, A. (2003). 'On the heterogeneity bias of pooled estimators in stationary VAR specifications', International Monetary Fund Working Paper WP/03/73, Washington, DC: IMF.

Romer, T., Rosenthal, H. and Munley, V. (1992). 'Economic incentives and political institutions: Spending and voting in school budget referenda', Journal of Public Economics, 49, pp. 133.

Russian Federation (1995). Human Development Report, Moscow: Government of Russian Federation.

Schultz, T. P. (1996). 'Accounting for public expenditures on education: An international panel study', in Schultz, T. P. (ed.) Research in Population Economics, Vol. 8, Greenwich, CT: JAI Press Inc.

TACIS (2001). Sectoral Public Expenditure Reviews, Tacis European Expertise Service Programme.

Wooldridge, J. (2002). Econometric Analysis of Cross Section and Panel Data, Cambridge, MA: MIT Press.

World Bank (2001). Peruvian Education at Crossroads: Challenges and Opportunities for the $21^{\text {st }}$ Century, Country Study, Washington, DC: The World Bank. 


\section{Appendix}

Table 1. Results from panel data estimation using the GLS random-effects model (Dependent variable: Log of per capita education expenditures (CPEDEXP))

\begin{tabular}{|c|c|c|c|}
\hline Variable & Coefficient estimate & z-statistic & P>abs. 2 \\
\hline Constant & 2.027 & 7.01 & 0.000 \\
\hline $\operatorname{Ln}(\mathrm{CPREV})$ & 0.572 & 22.21 & 0.000 \\
\hline STUDPPOP & 0.003 & 4.29 & 0.000 \\
\hline $\operatorname{Ln}(P D E N C)$ & -0.040 & -4.31 & 0.000 \\
\hline R1 & 0.163 & 2.87 & 0.004 \\
\hline R7 & -0.120 & -2.37 & 0.018 \\
\hline R8 & 0.104 & 2.13 & 0.033 \\
\hline Adj. R-square & & 0.90 & \\
\hline Number of observations & & 174 & \\
\hline Wald Test [chi-square(6)] & & 951.82 & \\
\hline Prob $>$ chi-square & & 0.000 & \\
\hline \multirow[t]{3}{*}{ Breusch-Pagan Lagrange Multiplier test: } & \multicolumn{3}{|c|}{ Null Hypotheses: $\operatorname{Var}(u)=0$} \\
\hline & \multicolumn{3}{|c|}{ Calculated Chi-square $(\mathbf{1})=33.85$} \\
\hline & \multicolumn{3}{|c|}{ Prob $>$ chi-square $=0.000$} \\
\hline \multirow[t]{3}{*}{ Hausman Specification test: } & \multicolumn{3}{|c|}{$\begin{array}{l}\text { Null Hypothesis: No systematic } \\
\text { difference in coefficients }\end{array}$} \\
\hline & \multicolumn{3}{|c|}{ Calculated Chi-square $(\mathbf{1})=0.96$} \\
\hline & \multicolumn{3}{|c|}{ Prob $>$ chi-square $=0.617$} \\
\hline
\end{tabular}

Note: The variables CPEDEXP, CPREV, STUDPPOP, and PDENC represent per capita educational expenditures, total tax revenue, student-population ratio and population density, respectively. $\mathrm{R} 1, \mathrm{R} 7$, and $\mathrm{R} 8$ are the three regional variables. Ln represents the logarithm of the variables. 


\section{Table 2. Estimation of price elasticity (Dependent variable: Log of per capita education expenditures (CPEDEXP))}

\begin{tabular}{lccc}
\hline Variable & Estimate & z-statistic & Prob>abs. z \\
\hline Constant & 0.717 & 1.39 & 0.166 \\
Ln(CPVA) & 0.623 & 13.79 & 0.000 \\
Ln(RREV) & -0.177 & -2.55 & 0.011 \\
STUDPPOP & 0.005 & 4.16 & 0.000 \\
Ln(PDENC) & -0.092 & -8.01 & 0.000 \\
Adj. R-square & & 0.81 & 176 \\
Number of observations & \multicolumn{3}{c}{444.49} \\
Wald test [chi-square(4)] & Null Hypothesis: Var $(u)=0$ \\
Prob>chi-square & Calculated Chi-square $(1)=45.14$ \\
Breusch-Pagan Lagrangian multiplier test: & Prob>chi-square = 0.000 \\
& Null Hypothesis: No systematic \\
Hausman specification test: & differences in coefficients \\
& Calculated Chi-square $(2)=1.04$ \\
& Prob>chi-square = 0.791 \\
\hline
\end{tabular}

Note: CPVA measures value added within the region. For a description of the other variables, see notes to Table 1. 
Table 1A. Summary statistics of the variables

\begin{tabular}{|c|c|c|c|c|c|c|}
\hline Variable & Obs. & Mean & Std. Dev. & Min & Max & Units \\
\hline rev99 & 88 & 7238043 & 11400000 & 208781 & 87700000 & th rub \\
\hline revw99 & 88 & 6468615 & 11400000 & 29767 & 87700000 & th rub \\
\hline Rrev99 & 88 & 0.7465886 & 0.2298897 & 0.142575 & 1 & \\
\hline value_ad99 & 88 & 43492.64 & 79670.83 & 335.2925 & 695059.8 & 1000 th rub \\
\hline edexp99 & 88 & 1414195 & 1489510 & 55398 & 9480594 & th rub \\
\hline revo0 & 88 & 11800000 & 24000000 & 377581 & 196000000 & th rub \\
\hline value_ad00 & 88 & 66047.19 & 136091.5 & 654.4382 & 1193130 & 1000 th rub \\
\hline revw00 & 88 & 10600000 & 24100000 & 59773 & 196000000 & th rub \\
\hline Rrev00 & 88 & 0.7350746 & 0.2396516 & 0.126984 & 1 & \\
\hline edexp00 & 88 & 1964396 & 2216296 & 92276 & 14200000 & th rub \\
\hline gks_index & 88 & 1.10 & 0.39 & 0.77 & 3.25 & \\
\hline ra1 & 87 & 0.0689655 & 0.2548645 & 0 & 1 & \\
\hline ra7 & 87 & 0.1034483 & 0.306309 & 0 & 1 & \\
\hline ra8 & 87 & 0.091954 & 0.2906362 & 0 & 1 & \\
\hline $\mathrm{ra9}$ & 87 & 0.1034483 & 0.306309 & 0 & 1 & \\
\hline PDENC & 88 & 161 & 975 & 0.02 & 8589 & persons $/ \mathrm{km}^{2}$ \\
\hline POP & 88 & 1626 & 1470 & 19 & 8537 & th people \\
\hline STUDPPOP & 88 & 158 & 24 & 120 & 236 & per 1000 \\
\hline
\end{tabular}

